\begin{tabular}{|l|l|l|l|l|l|}
\hline J. Tek. Ling. & Vol.10 & No.1 & Hal. 42 - 53 & Jakarta, Januari 2009 & ISSN 1441-318X \\
\hline
\end{tabular}

\title{
MIKROALGAE SEBAGAI SUMBER ENERGI TERBARUKAN YANG RAMAH LINGKUNGAN
}

\author{
Sarmidi Amin \\ Peneliti di Pusat Teknologi Agroindustri - Kedeputian TAB \\ Badan Pengkajian dan Penerapan Teknologi
}

\begin{abstract}
Microalgae as biomass are a potential source of renewable energy and they can be converted into energy such as biofuel oil and gas. This paper presents a brief review on the main conversion process of microalgae becoming energy. Since microalgae have high water content, then not all biomass energy conversion processes can be applied. By using thermochemical process it can be produced oil and gas, and by using biochemical process it can be produced ethanol and biodiesel. The properties of microalgae product is almost similar to offish and vegetables oil and therefore it can be considered as a substitute of fossil oil.
\end{abstract}

Keywords: Biofuel; Oil production; Microalgae; Thermoche-mical; Biochemical

\section{LATAR BELAKANG}

Ada dua isu penting saat ini yaitu krisis bahan bakar minyak (BBM) dan pemanasan global. Penggunaan bahan bakar fosil dipercaya akan meningkatkan pemanasan global. Penggunaan energi biomassa diketahui dapat menurunkan emisi gas $\mathrm{CO}_{2}$ Ada beberapa sumber energi biomassa yang sedang dikembangkan di beberapa negara. Penggunaan ganggang (microalgae) sebagai salah satu bahan baku mempunyai prospek cerah karena mikroalgae mudah dibudidayakan dan dapat berproduksi lebih banyak dibanding bahan baku lainnya.

Pemanasan global dipengaruhi oleh peningkatan konsentrasi gas akibat pengaruh rumah kaca di atmosfir dan sekarang menjadi perhatian masyarakat dunia ${ }^{1}$. Untuk mengurangi konsentrasi $\mathrm{CO}_{2}$ di atmosfir dapat dilakukan metoda berikut ${ }^{2}$ :

1). Pengurangan penggunaan bahan bakar fosil
2). Pengurangan $\mathrm{CO}_{2}$ dari atmosfir, misalnya dengan Penghijauan kembali hutan yang telah gundul

3). Mengurangi $\mathrm{CO}_{2}$ dari cerobong asap sebelum dilepas ke atmosfir

Telah diketahui secara luas bahwa energi biomassa mempunyai konstribusi sebagai penyedia sumber energi di berbagai kegiatan di pedesaan ${ }^{3,4}$. Bio-massa dihasilkan dari beberapa tanaman atau dari limbah perkebunan ${ }^{5}$, bahkan sampah rumah tangga dan industri dapat digunakan sebagai bahan ${ }^{6}$.

Menurut Shay, bahan bakar ${ }^{7}$, mikroalgae adalah bahan yang mempunyai efisiensi fotosintetik terbesar dibanding biomassa lainnya. Oleh karena itu jika kita dapat mengekstrak minyaknya secara efisien, maka ganggang dapat dijadikan sumber pengganti BBM, ${ }^{3,8}$. Penyerapan $\mathrm{CO}_{2}$ dan produksi energi dari ganggang diharapkan dapat mengurangi krisis 
energi ${ }^{9,10)}$. Telah diketahui pula bahwa $\mathrm{CO}_{2}$ adalah sumber untuk pertumbuhan ganggang ${ }^{11)}$. dengan menggunakan mikroalgae, selain $\mathrm{CO}_{2}$ dalam udara dapat dikurangi, dengan konversi biologi atau thermokimia akan diperoleh minyak ${ }^{11,12)}$. Mikroalgae mengandung lipid dan asam lemak (fatty acids) sebagai komponen membran, storage products, metabolites dan sumber energi11).

Makalah ini membahas beberapa metoda mengkonversi ganggang menjadi bahan bakar cair dan gas, biodiesel dan bioethnol.

\section{KONVERSI ENERGI BIOMASSA}

Keuntungan pengembangan mikroalgae sebagai sumber biomassa ada-lah ${ }^{13)}$ :

1). Ganggang dianggap suatu sistem biologi yang sangat efisien dalam memanfaatkan energi matahari untuk memproduksi senyawa organik.

2). Ganggang adalah tanaman nonvascular, kurang memreproduksi organ-organ komplek.

3). Banyak spesies ganggang yang menghasilkan komponen yang berharga secara komersial seperti protein, karbohidrat, lipid dan pigmen.

4). Ganggang adalah mikro-organisma yang mengalami pemecahan sel secara sederhana.

5). Ganggang dapat tumbuh di laut atau air tawar.

6). Ganggang dapat beradaptasi dari berbagai tingkat operasional.

Ganggang adalah tumbuhan yang mengandung minyak tertinggi. la dapat menghasilkan 100.000 liter minyak per ha per tahun, sementara sawit, kelapa, jarak dan bunga matahari masing-masing hanya menghasilkan 5.950, 2.689, 1.413, dan 952 liter per ha per tahun ${ }^{14)}$

Aquatic Species Program (ASP) menganggap ada 3 produk utama bahan bakar dari biomassa ${ }^{15)}$ yaitu gas methan, ethanol dan biodiesel. Sebenarnya masih ada yang keempat yaitu pembakaran langsung terhadap ganggang dan menghasilkan uap atau listrik, tetapi ASP tidak menaruh perhatian pada masalah ini.

Beberapa macam ganggang mempunyai kandungan minyak melebihi $80 \%$ dari berat kering biomassanya ${ }^{16,17)}$ dan menurut oilgae ${ }^{14)}$, ada beberapa yang mempunyai minyak 15-40\% (berat kering), sementara palm kernel mempunyai $50 \%$, kopra sekitar $60 \%$, bunga matahari $55 \%$. Kadar minyak sendiri diperkirakan sekitar $64.4 \%$ dari total lipid ${ }^{18)}$.

Konversi energi biomassa menjadi minyak adalah dengan metoda biokimia, thermokimia dan pembakaran lang-sung ${ }^{4,19}$. Konversi biokimia lebih lanjut dapat dibagi menjadi fermentasi, anaerobic digestion, bioelectrochemical fuel cells, dan menggunakan meta-bolisma dari organisma. Konversi thermokimia dapat dibagi menjadi gasifikasi, pirolisa dan liquefaction. Gambar 1 menunjukkan proses konversi energi dari mikroalgae. Biomassa dapat juga dikonversi menjadi 3 produk utama, dua hubungannya dengan energi dan satu sebagai feedstock kimia ${ }^{5)}$.

Diketahui bahwa mikroalgae mengandung air dalam jumlah yang banyak $(80-90 \%)^{16)}$; oleh karena itu tidak semua metoda proses konversi energi dari biomassa dapat dipakai terhadap bahan ini. Sebagai contoh, pembakaran langsung hanya bagus dilakukan jika kandungan air dibawah 50\%. Kandungan air yang tinggi hanya cocok untuk konversi secara biologi5).

\section{PRODUKSI MIKROALGAE}

\subsection{Budidaya}

Ganggang dapat dibudidayakan dalam berbagai sistem ${ }^{20)}$. Untuk skala kecil atau skala laboratorium, budidaya menggunakan fermentor atau foto-bioreaktor ${ }^{11,21)}$ atau tanki air berbentuk kotak $^{11)}$. Fermentor menggunakan lampu fluoresen sebagai pengganti sumber sinar matahari, dengan derajat iradiasi sekitar 10,000 Ix atau 20,000 $\mathrm{IX}^{11)}$ atau menggunakan distributor sinar lainnya ${ }^{21)}$. 


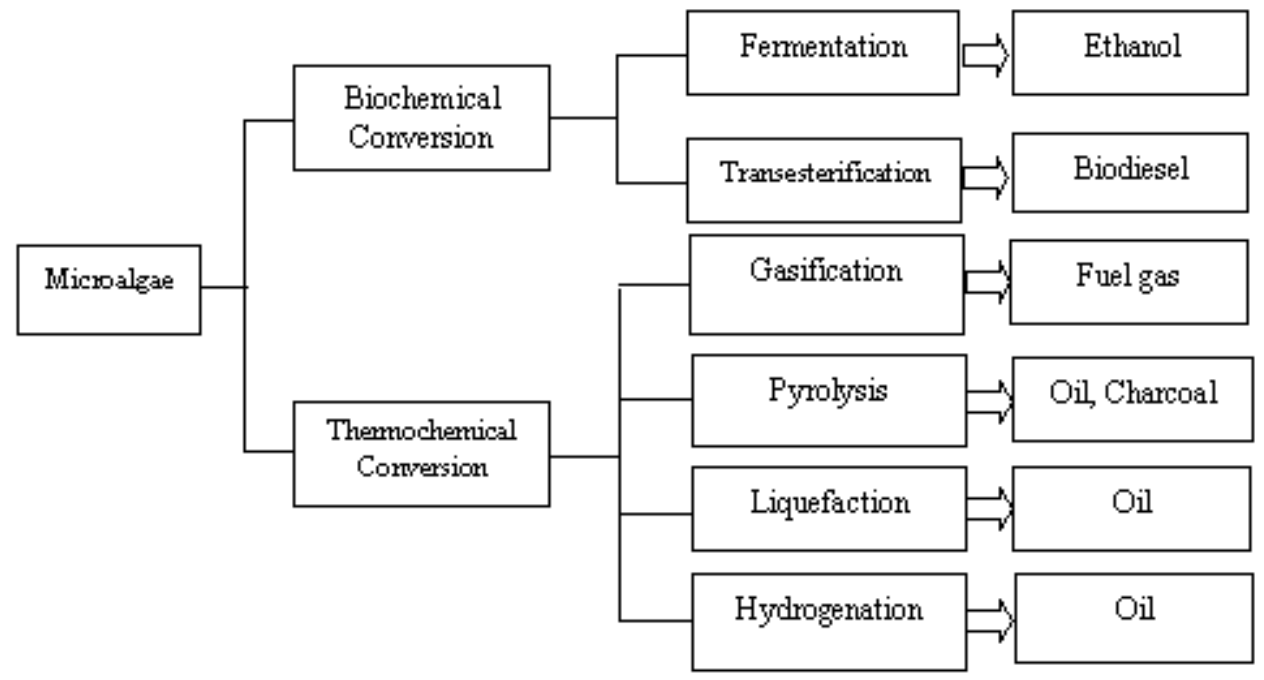

Gambar 1. Konversi Energi Mikroalgae

Keuntungan penggunaan fotobioreaktor adalah dapat menyerap panas matahari dan mengurangi kontaminasi ${ }^{21)}$. Untuk yang berskala besar, mikroalgae dapat ditumbuhkan pada sistem kolam terbuka atau tertutup ${ }^{21,22)}$. Yang termasuk kolam terbuka alami adalah danau, situ, parit dan kolam terbuka buatan misalnya kolam atau kontainer. Yang sering digunakan adalah shallow big ponds, tanki, kolam melingkar (circular ponds) dan kolam pacu (raceway ponds) ${ }^{21,22)}$.

Tubular photobioreactor adalah tipe yang cocok dipasang diluar rumah. Tubular photobioreactors biasanya terbuat dari gelas atau plastik transfaran dan airnya disirkulasi dengan pompa atau sistem hembusan udara (air lift sys-tem $)^{21)}$. Tubular photobioreactors mem-punyai keuntungan yaitu dapat didirikan pada tempat terbuka, dapat dioperasikan dengan konsentrasi biomassa yang tinggi dan terjaga dari kontaminan dari udara lingkungan ${ }^{23)}$ dan dapat memproduksi biomassa ganggang dalam skala industri ${ }^{16)}$. Tabung solar collector biasa-nya berdiameter sekitar 0.1 $\mathrm{m}$ atau kurang. Diameter tabung dibatasi karena sinar tidak dapat menembus terlalu dalam pada ganggang yang tebal dan produktivitas photobioreaktor yang tinggi ${ }^{17)}$. Tabung gelas atau plastik yang dipasang berdiri dapat diganti dengan selang plastik yang dililitkan pada rangka dan membentuk helical coil tubular photobioreactor ${ }^{17}$.

\subsection{Panen dan prosesing}

Ganggang dapat dipanen menggunakan microscreens, sentrifugasi, atau dengan cara penggumpalan (floccu-lation). Alum dan ferric chloride adalah bahan kimia untuk penggumpalan ganggang saat panen ${ }^{24)}$. Bahan penggumpal lain adalah chitosin $^{24,25)}$. Panen dengan bahan penggumpal dianggap metoda yang mahal pada skala industri. Cara yang lebih murah adalah dengan menghentikan asupan $\mathrm{CO}_{2}$ sehingga mikroalgae akan menggumpal sendiri. Hal ini disebut dengan autoflocculation $^{24)}$. Ganggang yang akan diproses dengan cara liquefaction dapat dipanen dengan separator sentrifugal ${ }^{7}$.

Minyak dari ganggang dapat diekstrak dengan beberapa cara ${ }^{24,26)}$ :

1). Ganggang dikeringkan dan di-press.

2). Minyak dapat diekstrak dengan bahan kimia seperti benzene, ether atau heksan. Metoda ini dapat 
dikombinasikan dengan press dingin. Kombinasi proses tersebut dapat mengeluarkan lebih dari $95 \%$ total minyak yang ada dalam ganggang.

3). Ekstrak dengan enzim.

4). Osmotic shock adalah mengurangi tekanan osmotik dengan tiba-tiba; dimana hal ini dapat menyebabkan rusaknya sel.

5). Pada metoda superkritikal, $\mathrm{CO}_{2}$ dicairkan dengan tekanan dan pemanasan sampai titik dimana material bersifat cair dan gas. Fluida yang dicairkan kemudian bertindak sebagai pelarut dalam mengekstrak minyak.

6). Minyak dari ganggang dapat juga di ekstrak dengan metoda lain ${ }^{27)}$. Ganggang di hancurkan dengan alat menjadi bubuk dan dikeringkan selama 20 menit pada $80^{\circ} \mathrm{C}$ dalam inkubator untuk menghilangkan air. Heksan dan pelarut ether lainnya dicampur dengan bubuk ganggang dan diekstrak menjadi minyak, kemudian dicampur selama 24 jam untuk pengendapan.

\section{KONVERSI ENERGI}

\subsection{Konversi Thermokimiawi}

\subsubsection{Gasifikasi}

Gasifikasi adalah proses yang berlangsung pada temperatur tinggi (800$900^{\circ} \mathrm{C}$ ) dan oksigen yang terbatas, namun ada juga yang beroperasi pada suhu rendah ${ }^{28}$. Peneliti Elliot mengem-bangkan metoda gasifikasi katalitik temperatur rendah dengan kandungan air yang sangat tinggi ${ }^{29)}$. Biomassa dengan kandungan air yang sangat tinggi dapat digasifikasi secara langsung menjadi gas methan tanpa pengeringan lebih dulu. Jika ditambah dengan nitrogen maka akan menjadi amonia selama terjadi reaksi ${ }^{28)}$.

\subsubsection{Liquefaction}

Mikroalgae hasil panen dengan sentrifugasi akan mempunyai kandungan air yang tinggi sehingga cocok untuk bahan baku proses liquefaction ${ }^{11,16)}$. Gambar 2 adalah skematis proses liquefaction $n^{7,11,30,-33)}$. Liquefaction ter jadi pada temperatur $300^{\circ} \mathrm{C}$ dan tekanan $10 \mathrm{MPa}$ tanpa pengurangan gas hidrogen dan atau karbon monoksida ${ }^{7)}$.

Liquefaction dilakukan di dalam autoclave stainless steel yang dilengkapi dengan pengaduk. Ganggang dima-sukkan ke reaktor kemudian diikuti dengan gas nitrogen dan dipanaskan pada temperatur tertentu. Suhu dijaga konstan selama 5 sampai 60 menit dan diikuti dengan proses pendinginan. Hasil reaksi diekstrak dengan dichloromethane untuk memisahkan fraksi minyak. Hasil ekstraksi dipisahkan dan diuapkan pada suhu $35^{\circ} \mathrm{C}$ dibawah pengaruh tekanan rendah dan menghasilkan material lunak berwarna coklat gelap lunak (darkbrown viscous). Hasil ekstrak tersebut kemudian difiltrasi ${ }^{7,11)}$.

\subsubsection{Pirolisa}

Pirolisa adalah proses merubah biomassa menjadi bahan bakar dengan cara pembakaran pada kondisi sangat minim udara dengan suhu sekitar $500^{\circ} \mathrm{C}^{5,34)}$ dan diberi katalisator ${ }^{35)}$, mempunyai laju pemanasan yang tinggi $\left(10^{3}-10^{4} \mathrm{~K} / \mathrm{s}\right)$ dan waktu tinggal gas yang sangat pendek untuk merusak rantai molekul sehingga menjadi pendek dan kemudian didinginkan dengan cepat ${ }^{36)}$.

Proses pirolisa ada yang berjalan lambat dan ada pula yang berjalan cepat. Keuntungan proses yang berjalan cepat adalah diperoleh bahan bakar cair secara langsung ${ }^{37)}$ dan efisiensi konversi sampai $80 \%$. Prinsip dari pirolisa cepat fluidized bed dapat dilihat pada gambar $3^{37)}$.

\subsubsection{Hidrogenasi}

Hidrogenasi adalah reaksi kimia yang terjadi dengan penambahan hidrogen $\left(\mathrm{H}_{2}\right)$ 
dan menggunakan kata-lisator ${ }^{38}$. Proses hidrogenasi ganggang dapat dilakukan dengan suhu dan tekanan tinggi. Pada proses ini ada tiga fase bahan yaitu fase gas (hidrokarbon dan hidrogen), fase cair (campuran pelarut dan produk cair), fase padat (ganggang dan katalis) ${ }^{11}$.

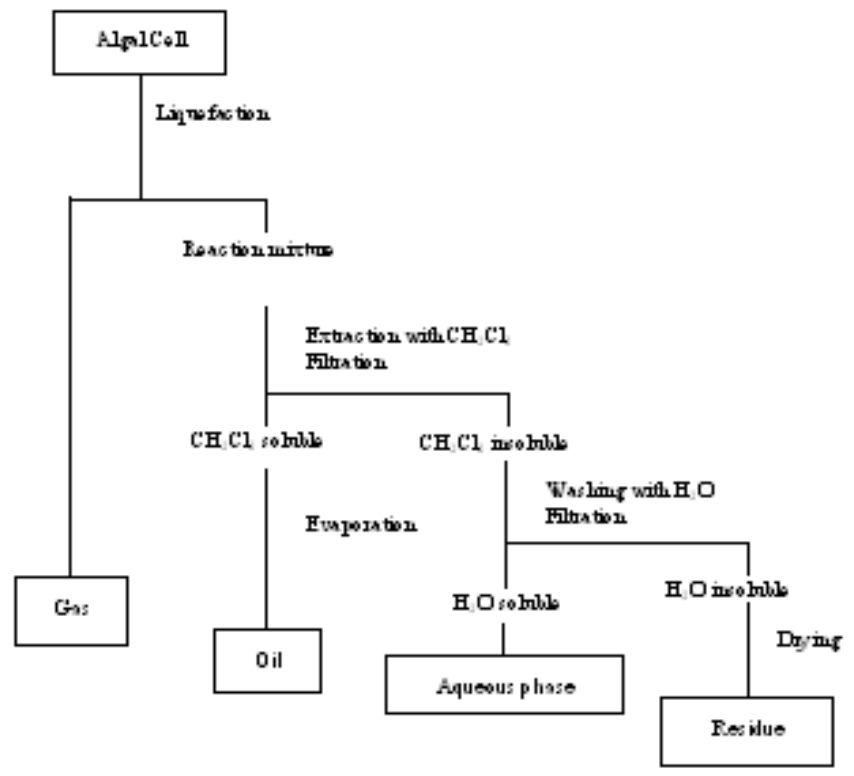

Gambar 2. Skematis Separasi Ganggang Secara Liquefaction

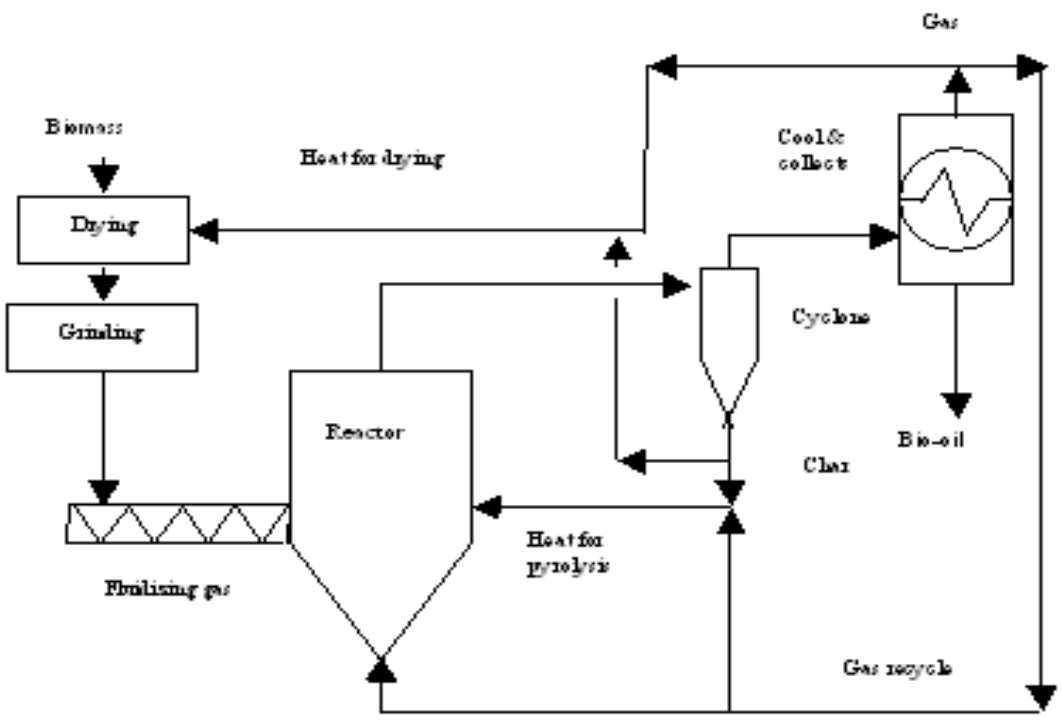

Gambar 3. Prinsip Proses Pirolisis Cepat 


\subsection{Konversi Biokimia}

\subsubsection{Fermentasi}

Fermentasi ganggang dapat menghasilkan ethanol. Adapun tahapan prosesnya adalah budidaya mikroalgae, pemanenan, slurry preparation, fermentasi, dan proses separasi ethanol ${ }^{9}$.

Peneliti lain ${ }^{39)}$ memproduksi ethanol dengan fermentasi dalam kondisi gelap terhadap ganggang laut hijau Chlorococcum littorale. Pada kondisi gelap dan anaerobic, $27 \%$ cellular starch dikonsumsi selama 24 jam pada $25^{\circ} \mathrm{C}$. Cellular starch didekomposisi lebih cepat pada suhu yang lebih tinggi dan akan diperoleh ethanol, asetat, hidrogen dan karbon dioksid. Produktivitas maksimum ethanol adalah 450 ì mol/g-berat kering pada suhu $30^{\circ} \mathrm{C}$.

\subsubsection{Transesterifikasi}

Transesterifikasi adalah reaksi lemak atau minyak dengan alkohol dan membentuk ester dan gliserol atau gliserin ${ }^{35)}$. Untuk reaksi biasanya diberi katalisator asam atau basa ${ }^{35}$, homogen atau heterogen ${ }^{40}$. Hasil transesterifikasi adalah biodiesel. Agar supaya diperoleh produksi yang tinggi, alkohol yang digunakan harus dalam jumlah yang berlebih (excess) $^{41)}$.

Proses produksi biodiesel adalah relatif mudah. Beberapa situs meng-ajarkan cara pembuatannya, misalnya journey to forever ${ }^{42)}$, biodiesel techno-logies India ${ }^{43)}$, dan dangerous labora-tories ${ }^{44}$. Gambar 4 adalah skematis proses produksi biodiesel. Langkah pertama adalah pengurangan kadar air dari minyak dengan cara peningkatan temperatur minyak sampai $120^{\circ} \mathrm{C}$ selama beberapa menit. Setelah itu, minyak didinginkan. Bersamaan dengan itu, melalukan pencampuran sodium hidrok-sida dan methanol, dengan cara pengadukan sampai menjadi larutan sodium methoksida. Minyak dipanaskan kembali sampai sekitar $60^{\circ} \mathrm{C}$ dan kemudian larutan sodium methoksida dicampurkan ke minyak dan diaduk selama 30 menit. Setelah selesai pengadukan, biarkan larutan menjadi dingin dan memisah. Proses separasi berlangsung sekitar 15-60 menit. Methil ester (ME) atau biodiesel akan berada di lapisan atas, gliserin akan berada di bagian bawah. Tahap terakhir adalah melakukan pencucian, pengeringan dan pengujian kualitas.

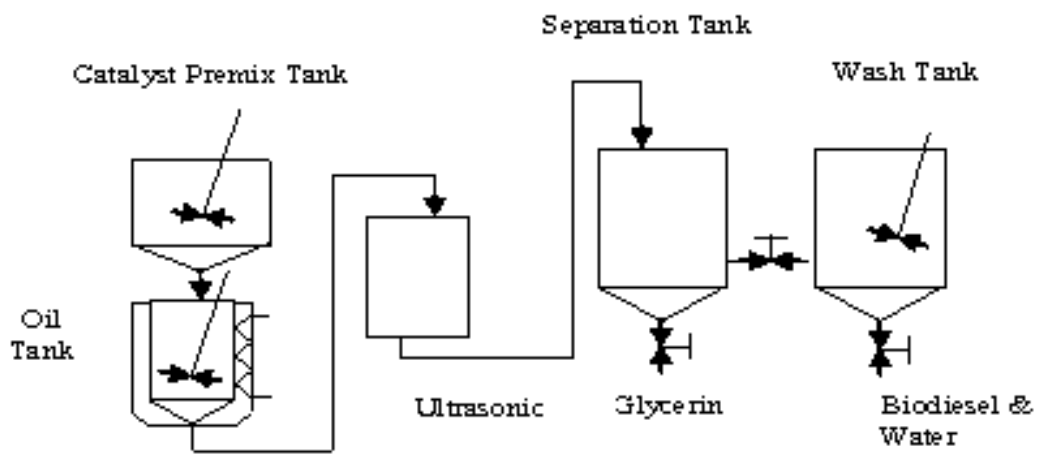

Gambar 4. Skematis proses produksi biodiesel

\section{HASIL PROSES KONVERSI}

\subsection{Gasifikasi}

Gasifikasi akan menghasilkan gas bakar seperti $\mathrm{H}_{2}, \mathrm{CH}_{4}, \mathrm{CO}_{2}$, dan ammo-nia.
Gas tersebut mempunyai nilai kalor yang rendah (sekitar 4-6 $\mathrm{MJ} / \mathrm{N} \mathrm{m}^{3}$ ) dan dapat terbakar secara langsung atau dibakar sebagai bahan bakar turbin gas atau sebagai bahan baku gas sintetik pada industri kimia $^{5}$. 


\subsection{Liquefaction}

Menurut FAO hasil liquefaction mikroalgae adalah minyak berat atau ter dengan produksi (yield) $35.6 \%$, atau dalam kisaran $31-44 \%{ }^{7}$ atau kisaran $30-40 \%{ }^{19}$. Minyak berat tersebut terdiri dari karbon $(73 \%)$, hidrogen $(9 \%)$, nitrogen $(5 \%)$, dan oksigen (13\%). Nilai kalor (heating value) minyak berat adalah $34.7 \mathrm{~kJ} / \mathrm{g}$, atau hampir sama dengan minyak berat tipe $\mathrm{C}$. Minyak berat ganggang mempunyai kekentalan 860 $\mathrm{cps}$, atau hampir sama dengan minyak jarak (castor oil). Minyak berat ini mempunyai kandungan nitrogen yang lebih tinggi dari minyak bumi, sehingga membutuhkan perlakuan khusus agar tidak terjadi pembentukan $\mathrm{N}_{\text {ox }}$ pada sistem gas buangnya.

Minowa $^{7)}$ melaporkan bahwa pro-duksi minyak dengan metoda direct hydrothermal liquefaction kira-kira 37\% (organic basis) pada suhu $300^{\circ} \mathrm{C}$ dan $10 \mathrm{MPa}$ dari

\subsection{Pirolisa}

Proses pirolisa akan menghasilkan bahan bakar yang dapat digunakan pada mesin dan turbin gas atau sebagai bahan baku industri ${ }^{5}$ atau digunakan pada mesin diese ${ }^{35}$. Minyak yang diperoleh mempunyai nilai kalor $17 \mathrm{MJ} / \mathrm{kg}$ atau lebih rendah dari bahan bakar konven-sional yaitu sekitar 42$44 \mathrm{MJ} / \mathrm{kg}^{37}$. Menurut $\mathrm{Miao}^{34)}$, nilai kalor minyak dari ganggang rata-rata adalah 29 $\mathrm{MJ} / \mathrm{kg}$, atau kira-kira 1,4 kali nilai kalor kayu.

\subsection{Hidrogenasi}

Ganggang dapat dirubah menjadi hidrokarbon cair pada suhu $400-430^{\circ} \mathrm{C}$, dengan tekanan 7-14 MPa, dan katalisator cobalt molybdate. Produksi tertinggi diperoleh $46.7 \mathrm{wt} \%$. Sebagai tambahan, sekitar $10 \mathrm{wt} \%$ produk cair dan $34 \mathrm{wt} \%$ gas kaya hidrocarbon. Pada umumnya, suhu tinggi dan lebih lama waktu reaksinya akan

Tabel 1. Produksi Methan dan Karbon Dioksida ini pada Proses Liquefaction ${ }^{31)}$

\begin{tabular}{cccccc}
\hline $\begin{array}{c}\text { Holding time } \\
\text { (min) }\end{array}$ & $\begin{array}{c}\mathrm{Na}_{2} \mathrm{CO}_{3} \\
\text { dosage (wt.\%) }\end{array}$ & $\begin{array}{c}\text { Reaction temp } \\
\left({ }^{\circ} \mathrm{C}\right)\end{array}$ & $\begin{array}{c}\text { Gas } \\
\text { volume } \\
(0)\end{array}$ & & \multicolumn{2}{c}{ Concentration (ppm) } \\
\cline { 6 - 7 } 30 & 0 & 300 & 1.1 & $\mathrm{CH}_{4}$ & $\mathrm{CP}_{2}$ \\
\hline & 0 & 340 & 1.1 & 376 & 1250 \\
& 5 & 300 & 1.4 & 31 & 625 \\
& 5 & 340 & 1.5 & 227 & 1300 \\
\hline \multirow{2}{*}{60} & 0 & 300 & 1.7 & 65 & 250 \\
& 0 & 340 & 1.5 & 352 & 1300 \\
& 5 & 300 & 1.5 & 74 & 750 \\
& 5 & 340 & 1.8 & 283 & 650 \\
\hline
\end{tabular}

mikroalgae jenis Dunaliella tertiolecta yang berkadar air $78.4 \mathrm{wt} \%$. Minyak diperoleh pada suhu reaksi $340^{\circ} \mathrm{C}$ dan berlangsung selama 60 menit dan mempunyai kekentalan 150-330 mPass dan nilai kalor $36 \mathrm{~kJ} / \mathrm{g}$. Pada riset yang serupa, minyak yang diperoleh dari Botryococcus braunii, produksi mak-simum $64 \%$ (dari berat kering) dengan suhu proses $300^{\circ} \mathrm{C}$ dan katalisator sodium karbonat ${ }^{16,45)}$. meningkatkan derajat konversinya dan mengurangi produksi ter. Produksi dan konversinya akan meningkat proporsional dengan tekanan hidrogen sampai maksimum 8.2 $\mathrm{MPa}^{11)}$. Peneliti lain menggunakan temperatur dan tekanan sangat tinggi akan menghasilkan produksi sampai mendekati $50 \%{ }^{19}$. 
Tabel 2. Perbandingan Sifat Minyak Bumi dan Bio-oil dari Proses Pirolisa Cepat Kayu dan Mikroalgae ${ }^{34)}$

\begin{tabular}{|c|c|c|c|}
\hline \multirow[t]{3}{*}{ Properties } & \multicolumn{3}{|l|}{ Typical value } \\
\hline & \multicolumn{2}{|l|}{ Bio-oils } & \multirow{2}{*}{ Fossil oil } \\
\hline & Wood & Microalgae & \\
\hline$\overline{\mathrm{C}}$ & $56.4 \%$ & $61.52 \%$ & $83.0-87.0 \%$ \\
\hline $\mathrm{H}$ & $6.2 \%$ & $8.50 \%$ & $10.0-14.0 \%$ \\
\hline 0 & $37.3 \%$ & $20.19 \%$ & $0.05-1.5 \%$ \\
\hline$N$ & $0.1 \%$ & $9.79 \%$ & $0.01-0.7 \%$ \\
\hline$S$ & n.d. $a$ & n.d. & $0.05-5.0 \%$ \\
\hline Density & $1.2 \mathrm{~kg} \mathrm{l}^{-1}$ & $1.16 \mathrm{~kg} \mathrm{l}^{-1}$ & $0.75-1.0 \mathrm{~kg} \mathrm{l}^{-1}$ \\
\hline $\begin{array}{l}\text { Viscosity } \\
\text { (Pas) }\end{array}$ & $0.04-0.20$ (at $40^{\circ} \mathrm{C}$ ) & 0.10 (at $40^{\circ} \mathrm{C}$ ) & $\begin{array}{l}2-1000 \text { (depends on } \\
\text { temperature, density } \\
\text { and its contents etc.) }\end{array}$ \\
\hline $\begin{array}{l}\text { Heating } \\
\text { value }\end{array}$ & $21 \mathrm{MJ} \mathrm{kg}^{-1}$ & $29 \mathrm{MJ} \mathrm{kg}^{-1}$ & $42 \mathrm{MJ} \mathrm{kg}^{-1}$ \\
\hline Stability & $\begin{array}{l}\text { Not as stable as } \\
\text { fossil fuels }\end{array}$ & $\begin{array}{l}\text { Not as stable as } \\
\text { fossil fuels, but more } \\
\text { stable then the bio-oil } \\
\text { from wood }\end{array}$ & \\
\hline
\end{tabular}

a n.d. : not determined

\subsection{Fermentasi}

Dari proses fermentasi mikroalgae akan diperoleh ethanol. Ethanol dapat digunakan sebagai bahan bakar $(100 \%)$ atau sebagai gasohol atau campuran gasolin dan ethanol. Sebagai contoh mesin Flex-Fuel di Brazilia dapat berkerja dengan baik dengan $100 \%$ ethanol, $100 \%$ gasoline atau campuran keduanya, sedang di Amerika US Flex-Fuel Vehicle dapat berkerja pada $0 \%$ sampai $85 \%$ ethanol ( $15 \%$ gasolin $)^{46)}$.

Energi dari ethanol adalah $31.1 \mathrm{MJ} / \mathrm{kg}$ dan bilangan oktannya 129 , sementara itu energi dari gasolin adalah $44.4 \mathrm{MJ} / \mathrm{kg}$ dan bilangan oktan minimum 91 dan gasohol (90\% gasolin dan $10 \%$ ethanol) adalah 33.7 $\mathrm{MJ} /$ iter dan bilangan oktan 93/94 ${ }^{46}$. Ethanol dapat juga digunakan sebagai bahan bakar untuk pembangkit listrik direct-ethanol fuel cel/ $/^{46,47}$. Ethanol ada juga yang digunakan sebagai bahan bakar roket ${ }^{46)}$.

\subsection{Transesterifikasi}

Konversi triglycerides atau minyak menjadi biodiesel sekitar $98 \%{ }^{48)}$ atau lebih tinggi ${ }^{49)}$ dan digunakan sebagai bahan bakar alternatif mesin diesel. Spesifikasi standar biodiesel B100 (100\%) adalah ASTM D675144,50,51). Sifat fisik dari biodiesel dibanding dengan solar adalah seperti terlihat dalam Tabel 3.

Produk sampingan dari proses transesterifikasi adalah pembentukan sabun dan gliserin. Untuk mengurangi pembentukan sabun, peneliti menggunakan metoda superkritikal tanpa katalisator ${ }^{53)}$. Banyaknya gliserin yang terbentuk, menurut aturan (rule of thumb $)^{54,42)}$ adalah sebesar $79 \mathrm{ml}$ per liter minyak yang digunakan, tetapi kenyataan perolehannya berkisar 80-120 ml per liter minyak.

\section{KESIMPULAN}

Ganggang adalah sumber energi terbarukan yang sangat potensial dalam penyerapan $\mathrm{CO}_{2}$. Ganggang dapat dibudidayakan dalam photobioreaktor atau ditempat terbuka (open ponds).

Produksi mikroalgae per tahun (yield) minyak tertinggi dibanding dengan hasil 
perkebunan lainnya seperti kelapa, sawit, jarak dan bunga matahari. Kadar minyak ganggang $15-40 \%$ berat kering, tetapi ada juga yang sampai $80 \%$. Kandungan minyaknya dapat diperkirakan sekitar $64.4 \%$ dari komponen lipid total. Untuk mengekstrak minyak, dapat dilakukan dengan berbagai metoda.
3. Sawayama S, T. Minowa,. SY. Yokoyama, 1999; Possibility of renewable energy production and $\mathrm{CO}_{2}$ mitigation by thermochemical liquefaction of microalgae. J Biom Bioen 17: 33-39.

Tabel 3. Perbandingan Sifat-sifat Biodiesel, Diesel Fuel dan Standar ASTM ${ }^{52)}$

\begin{tabular}{|c|c|c|c|}
\hline Properties & $\begin{array}{l}\text { Biodiesel from } \\
\text { microalgae oil }\end{array}$ & Diesel fuel $^{a}$ & $\begin{array}{l}\text { ASTM biodiesel } \\
\text { standard }\end{array}$ \\
\hline Density $\left(\mathrm{kg} \mathrm{L}^{-1}\right)$ & 0.864 & 0.838 & $0.86-0.90$ \\
\hline $\begin{array}{l}\text { Viscosity (mm } \mathrm{m}^{2} \mathrm{~s}^{-1}, \mathrm{cSt} \text { at } \\
\left.40^{\circ} \mathrm{C}\right)\end{array}$ & 5.2 & $1.9-4.1$ & $3.5-5.0$ \\
\hline Flash point $\left({ }^{\circ} \mathrm{C}\right)$ & 115 & 75 & Min 100 \\
\hline Solidifying point $\left({ }^{\circ} \mathrm{C}\right)$ & -12 & $-50-10$ & - \\
\hline Cold filter plugging point ( $\left.{ }^{\circ} \mathrm{C}\right)$ & -11 & $-3.0(\max -6.7)$ & $\begin{array}{c}\text { Summer max } 0 \\
\text { Winter max }<-15\end{array}$ \\
\hline Acid value ( $\left.\mathrm{mg} \mathrm{KOH}{ }^{g-1}\right)$ & 0.374 & Max 0.5 & Max 0.5 \\
\hline Heating value (M.J kg-1) & 41 & $40-45$ & - \\
\hline HiC ratio & 1.81 & 1.81 & - \\
\hline
\end{tabular}

Proses gasifikasi menghasilkan gas seperti $\mathrm{H}_{2}, \mathrm{CH}_{4}, \mathrm{CO}_{2}$, dan ammonia, sedang dari proses pirolisa akan diha-silkan biofuel. Biofuel dapat digunakan pada turbin gas atau sebagai bahan baku industri refineries. Produk fermentasi akan menghasilkan ethanol. Ethanol dapat digunakan sebagai bahan bakar (100\% alkohol) atau gasohol. Dengan proses transesterifikasi, ganggang dapat dikonversi menjadi biodiesel.

\section{DAFTAR PUSTAKA}

1. Watanabe Y, DO. Hall. 1996; Photosynthetic $\mathrm{CO}_{2}$ conversion technologies using a photobioreactor incorporating microalgae-energy and material balances. J. En Conv Mgmt 37, 6-8: 1321-26.

2. Benemann JR. 1997, $\mathrm{CO}_{2}$ mitigation with microalgae systems. J En Conv Mgmt; 38: S475-79.
4. Tsukahara K, S. Sawayama. 2005; Liquid fuel production using microalgae. J Jpn Petro Inst 48, 5: 251-59.

5. McKendry P., 2003; Energy pro-duction from biomass (part 2): Conversion technologies. Biores tech 83: 47-54.

6. Minowa T, M. Murakami, Y. Dote, T. Ogi, S. Yokoyama, 1995; Oil production from garbage by thermochemical liquefaction. J Biom Bioen 8, 2: 117-20.

7. Minowa T, S. Yokoyama, M. Kishimoto, T. Okakurat, 1995; Oil production from algal cells of Dunaliella tertiolecta by direct thermochemical liquefaction. J Fuel 74, 12: 1735-38.

8. Tsukahara K, T. Kimura, T. Minowa, S. Sawayama, T. Yagishita, S. Inoue, T. Hanaoka, Y. Usui, T. Ogi, 2001; Microalgal cultivation in a solution recovered from the low temperature catalytic gasification of the microalga. J Biosci \& Bioengin 91, 3: 311-13. 
9. Hirayama S, R. Ueda, Y. Ogushi, A Hirano, Y. Samejima, KH. Nami, S. Kunito, 1998; Ethanol production from carbon dioxide by fermentative microalgae.In: Inui T, Anpo M, Izui K, Yanagida S, Yamaguchi T, editors. Advances in Chemical Conversions for Mitigating Carbon Dioxide, Studies in Surface Science and Catalysis 114, Elsevier Science BV: 657-60.

10. Hirano A, R. Ueda, S. Hirayama, 1997; $\mathrm{CO}_{2}$ fixation and ethanol production with microalgal photo-synthesis and intracellular anaerobic fermentation. Energy 22, 2/3:137-42.

11. FAO, Oil production, FAO Corp Doc Repository. Retrived on 05/02/2007 from www.fao.org/docrep/ w7241e/ w7241e0h.htm.

12. Yang YF, CP. Feng, Y. Inamori, T. Maekawa, 2004; Analysis of energy conversion characteristics in liquefaction of algae. Res Cons Recycl43: 21-33.

13. Vonshak A, 1990; Recent advances in microalgal biotechnology. Biotech. Adv. 8: 709-27.

14. Oilgae. Algal oil yields. Retrived on 07/ 18/2008 from http://www.oilgae. com/ algae/oil/yield/yield.html.

15. Sheechan J, T. Dunahay, J. Benemann, P. Roessler, 1998, Alook back at the U.S. Depart of Energy's Aquatic Species Program - Biodiesel from Algae NREL/TP-580-24190.

16. Patil V, KQ.Tran, HR. Giselrod, 2008; Toward sustainable production of biofuels from microalgae. Int J Mol Scie 9: 1188-95.

17. Christi Y, 2007; Biodiesel from microalgae. Biotech Adv 25: 294-06.

18. Hill AM, DA. Feinberg, 1984, Fuel from microalgae lipid products, to be presented at the Energy from Biomass: Building on a Generic Technology Base.
Second Tech Rev Meeting 23-25 April, Portland-Oregon.

19. Satin M. Microalgae. Retrieved on 06/ 16/2008 from http://www.fao.org/ ag/ ags/ Agsi/ MICROALG.htm.

20. Scragg AH, AM. IIman, A. Carden, SW. Shales, 2002; Growth of microalgae with increased calorific values in a tubular bioreactor. Biom Bioene 23: 6773.

21. Ugwu CU, H. Aoyagi, H. Uchiyama, 2008, Photobioreactors for mass cultivation of algae. Biores Tech; 99: 4021-28.

22. Borowitzka MA, 1999; Commercial production of microalgae: ponds, tanks, tubes, and fermenters. J Biotech 70: 313-12.

23. Torzillo G, B. Pushparaj, F. Bocci, W. Balloni, R. Materassi, G. Florenzano. 1986; Production of Sprirulina biomass in closed photobioreactors. Biomass 1: 61-74.

24. Wikipedia. Algaculture. Retrieved on 02/ 27/2007 from http://en.wikipedia. org/ wiki/Algaculture.

25. Morales J, J. Noûe, G. Picard, 1985; Harvesting marine microalgae species by chitosan flocculation. Aquacull Engin 4: 257-70.

26. Oilgae. Algae oil extraction. Retrie-ved on 02/27/2007 from http:// www.oilgae.com/algae/oil/extract/ extract.html.

27. Hossain ABMS, A. Salleh, 2008; Biodiesel fuel production from algae as renewable energy. Am J Bioche Biotech 4 (3): 250-54.

28. Minowa T, S. Sawayama, 1999; A novel microalgal system for energy production with nitrogen cCycling. Fuel 78: 1213-15.

29. Elliot DC, LJ. Sealock, 1999; Che-mical processing in high-pressure aqueous environments: low tempe-rature 
catalytic gasification. Trans. IChemE 74: 563-66.

30. Minowa T, T. Kondo, ST. Sudirjo, 1998; Thermochemical liquefaction of Indonesian biomass residues. Biom Bioen 14, 5/6: 517-24.

31. Yang Y.F, CP. Feng, Y. Inamori, T. Maekawa, 2004; Analysis of energy conversion characteristics in liquefaction of algae. Res Cons Recycl 43: 21-33.

32. Murakami M, S. Yokoyama, T.Ogi, K. Koguchi, 1990; Direct liquefaction of activated sludge from aerobic treatment of effluents from the cornstarch industry. Biom 23: 215-28.

33. Itoh S, A. Suzuki, T. Nakamura, S. Yokoyama, 1994; Production of heavy oil from seawage sludge by direct thermochemical liquefaction. Desal 98: 127-33.

34. Miao X, Q Wu, C Yang, 2004; Fast pyrolysis of microalgae to produce renewable fuels. J. Anal. Appl. Pyrolysis 71: 855-63.

35. Agarwal AK. 2007, Biofuel (alcohol and biodiesel) applications as fuel for internal combustion engine. Prog Ener Comb Scie; 33: 233-71.

36. Qi Z, C. Jie, W. Tiejun, X Ying, 2007; Review of biomass pyrolysis oil properties and upgrading research. En Conv Mngt 48: 87-92.

37. Bridgwater AV, GVC Peacocke, 2000; Fast pyrolysis processes for biomass. Renew Sust Energy Rev 4: 1 - 73.

38. Wikipedia. Hydrogenation, Retrieved on 07/02/200 from http://en. wikipedia. org/wiki/Hydrogenation.

39. Ueno Y, N. Kurano, S. Miyachi, 1998; Ethanol production by dark fermentation in the marine green alga, Chlorococcum littorale. J Ferm Bioengi 86 No.1: 38-43.
40. Pintoa AC, LLN. Guarieiroa, GMJC Rezendea, NM Ribeiroa, EA Torresb, WA. Lopesc, PAP Pereirac, JB Andrade, 2005; Biodiesel: an overview. J Braz Chem Soc 15, 5B: 1313-30.

41. Schuchardt U, R. Sercheli, RM. Vargas, 1998; Transesterification of vegetable oils a review. J Braz Chem Soc 9, 1: 199-210.

42. Journey to forever. Make your own biodiesel. Retrieved on 02/02/2006 from http: //journeytoforever.org/.

43. Anonymous. Biodiesel technology. Retrieved 07/12/2005 from http:// biodieseltechnologiesindia.com/ production.html.

44. Anonymous. Biodiesel. Retrieved 05/ 08/2006 from http://www. dangerouslaboratories.org/biodiesel.html.

45. Sawayama S, S. Inoue, Y. Dote, S. Yokoyama, 1995; $\mathrm{CO}_{2}$ fixation and oil production through microalga. En Convers Mgmt 36, 6-9: 729-731.

46. Wikipedia, Ethanol, Retrieved on 06/ 13/2008 from http://en.wikipedia. org/ wiki /Ethanol,

47. Bently J, R. Derby, Ethanol \& fuel cells: converging paths of oppor-tunity. Renewable Fuels Asso-ciation. Retrieved on 07/24/2008 from http:// www.ethanol rfa.org/ objects/ d o c u m e n t s / 129 / rfa_fuel_cell_white_paper.pdf,

48. Noureddini H, D. Harkey, V.A. Medikonduru, 1998; Continuous process for the conversion of vegetable oils into methyl esters of fatty acids. JAOCS 75, 12: 1775-83.

49. Anderson D, D. Masterson, B. McDonald, L. Sullivan, 2003; Industrial biodiesel plant design and engineering: practical experience. Presented at the Chemistry and Technology Conference. Interna-tional Palm Oil Conference (PIPOC), 24-28 August, Putrajaya Mariot Hotel, Malaysia. Retrieved on 06/ 
07/2007 from http://www.crow niron.com/userlmages/Biodiesel.pdf

50. He BB, AP. Singh, JC. Thomson; A Novel continuous-flow reactor using reactive distillation technique for biodiesel production. Retrieved on 11/ 01/2007 from http://www.webpa ges.uidaho.edu/ bhe/RD/RD.htm

51. Gerpen JV, Biodiesel production and fuel quality. Retrieved on 08/23/2007 from http://www.uidaho. edu/ bioe nergy/biodieselED/publication/01.pdf
52. Xu H, X Miao, QWu, 2006; High quality biodiesel production from a microalga Chlorella protothecoides by heterotrophic growth in fermen-ters. $J$ Biotech 126: 499-507.

53. Kusdiana D, S. Saka, Biodiesel fuel for fuel substitute prepared by a catalystfree supercritical methanol. Retrieved on 01/11/2007 from http://bioproductsbioenergy.gov.

54. Svlele. Transesterification biodiesel process. Retrieved on 12/12/2006 from www.svlele.com/biodiesel-process.htm. 